\title{
Creative heritage of V.I. Vernadsky and global challenges of sustainable development
}

\author{
Vladimir Grachev \\ Lomonosov Moscow State University
}

\begin{abstract}
The present article considers main aspects of creative heritage of V.I. Vernadsky in the sphere of global processes. It is shown that Vernadsky's theory of three main components of sustainable economic development (labor, capital, and creativity) is fundamental in the development of contemporary economy. The economic processes taking place in the present-day world are largely directed towards making a profit in the speculative turnover of capital, rather from using scientific and technological progress to meet the needs of people. The analysis of the interrelations of global problems of sustainable development in the economy, environment, and social sphere, allowed drawing the conclusion that the world could be destroyed by global fraud of speculative capital rather than by global warming. Based upon the latest report of the Club of Rome (2017), this path, disastrous for the modern world, has found understanding of the public. It is the aspiration for enrichment that creates some "global" problems. This is primarily related to the "global warming" problem. There is no such problem. There is a problem of global processes in the climate and the desire of economic elites to profit from this problem. The solution to global problems is associated with the noosphere balances and acceptable, equitable, and feasible conditions for sustainable development. The creative heritage of Vernadsky indicates the right way to address global challenges. This is creative thought, complementing the global natural balances based on homeostasis, and noospheric balances based on the world mind. Sustainable development embarks on a path of noosphere genesis, i.e. it is based on noospheric development, which is reasonable not only from the viewpoint of the mind of a single individual, but on the basis of the world mind and collective intelligence.
\end{abstract}

Key words: creative heritage of V.I. Vernadsky; role of scientific-and-technological advance in the development; global processes in economy, ecology, and social sphere.

\section{INTRODUCTION}

In the first quarter of the XXIst century, the world felt the reality of global problems. This is not only and not so much a problem of global warming, which is much talked about, but the problem of global pollution of the planet with waste that against the background of depletion of natural resources is really a serious problem, so much serious that the concept of anthropocene ${ }^{1}$ has already been introduced into circulation. Garbage islands in the oceans are also a kind of anthropocene, which is created by anthropogenic impact. But this is not the main thing. The main thing is that all this is happening in the conditions of growing inequality, poverty, and injustice, which together with the growing natural disasters really creates a threat to modern civilization.

Great Russian scientist Vernadsky addressed in his works almost all the problems. The study of his creative heritage can be useful in terms of meeting global challenges.

\footnotetext{
1 The anthropocene is a proposed epoch dating from the commencement of significant human impact on the Earth's geology and ecosystems including but not limited to anthropogenic climate change.
} 


\section{Creative heritage of V.I. Vernadsky}

Due to the efforts of the Vernadsky Ecological Foundation, a significant contribution has been made over the past five years to the study of the scientist's creative heritage [1-5].

Considering retrospectively the works of Vernadsky concerning the fundamental issues of sustainable development, one needs to start with his article issued in 1944 [6].

He writes: "In the geological history of the biosphere, a great future is opened to Man if he realizes it and does not direct his mind and work to self-destruction." Unfortunately, we are now witnessing that mind and work are directed towards creating a self-destruction system in a global confrontation. And it's not the biological nature of humanity that's to blame. Vernadsky writes: "Living matter, by weight, constitutes an insignificant part of our planet. Mankind's power is connected not with its matter but with its brain, its thoughts and its works, guided by its mind." We have directed the power of the mind to the creation of mass destruction weapons. At the same time, awareness of the fact of universal self-destruction leads to the fact that this weapon will become a deterrent. About the question whether mankind will be able assessing and using this weapon correctly, Vernadsky writes: "We are approaching a great revolution in the life of humankind, with which none of those it has experienced before can be compared. The time is not far off when a man will master atomic energy in his hands, a powerful source that will allow him to build up his life in accordance with his desire. It can happen within the coming years or it can happen in a century. But clearly, it will happen. Will he be able to use this force for good purposes and not for selfdestruction?" Has he grown to the point of using the power that science must inevitably give him? Scientists should not turn a blind eye to the possible consequences of their scientific work and scientific progress. They must feel responsible for the consequence of their discoveries. They must associate their work with the best organization of all mankind" [7].

These words resonate with the speech delivered by V.I.Vernadsky in February 1922 at the first public meeting of the Council State Radium Institute, whose director he was (Archive of the RAS, f.518, op.2, ed.khr.4, p.317 - 319). Later in a note addressed to the Council of People's Commissars, V.I. Vernadsky stressed that "the Radium Institute should now be organized so that it can direct its work to mastering atomic energy" (Ibid., P.518, op.2, ed.hr.46, p. 34). Radium Institute under the leadership of V.I. Vernadsky really managed to make an outstanding contribution to the solution of this problem. VI. Vernadsky himself considered the questions of radioactivity from the point of view of such sciences created as to a great extent by his efforts, such as genetic mineralogy, radiogeology, geochemistry, biogeochemistry; His role was also great in the search and exploration of radioactive minerals on the territory of the Russian Empire and the USSR, in the preparation and implementation of the Soviet atomic project.

"Thought and attention should be directed to these questions. And there is nothing in the world stronger than free scientific thought! Under difficult conditions of historical reality, the thought in this direction works poorly, and only in recent years, it seems to me, these questions for us are beginning to become questions of the day" [8].

The applicability of this persists even now $[2,4,9]$.

Realizing this, Vernadsky wrote in 1944 [6]: "The historical process is being radically changed under our very eyes. For the first time in the history of mankind the interests of the masses on the one hand, and the free thought of individuals, on the other hand, determine the course of life of mankind and provide standards for mere ideas of justice. Mankind taken as a whole is 
becoming a mighty geological force. There arises the problem of the reconstruction of the biosphere in the interests of freely thinking humanity as a single totality. This new state of the biosphere, which we approach without our noticing, is the noosphere".

Vernadsky began to develop these ideas since 1922, and after his speeches [8], Le Roy and Teilhard de Chardin have coined the term "noosphere".

It was V.I. Vernadsky who developed the notion "noosphere [11,12], and summarized in 1944 shortly before his death [6].

"The noosphere is the last of many stages in the evolution of the biosphere in geological history... - the state of our days. The course of this process is only beginning to become clear to us from the study of its geological past in certain of its aspects." [9].

This allowed developing further the theory of noosphere genesis [14]. Noospheric development (this term is more understandable) associates development with mind, i.e. with noospheric thinking and worldview.

An important feature of Vernadsky's noosphere idea is the clarification of the role of mind not only in the life of society, but through it, also in the evolution of the biosphere (especially geological evolution).

The correlation of mind and human activity is the core issue of noosphere, and, most likely, such ideas have widely begun to spread from the age of Enlightenment (although one can find the viewpoint that this started even since the times of antiquity), rather than since 1927, when E. Leroy used the term of "noosphere". It is the role and place of intelligent principles in social activity that determines the formation of the noospheric idea.

Of course, it is not a matter of the term of "noosphere", which due to the scientific authority of Vernadsky has largely become quite widespread in the USSR, and then in Russia and a number of post-Soviet countries. However, it is hardly necessary to consider that the ideas of noosphere are developed only in Russia, while in Europe and other countries these ideas have not taken root, and were forgotten after the works of French authors E. Leroy and Teilhard de Chardin. This term is used by just few people abroad, although in a number of countries and, oddly enough, in the United States, there are scientific organizations and works involved in this field [14].

The creative heritage of Vernadsky encompasses not only the contribution to the worldview, but also the contribution to particular sciences.

Figure 1 shows the proportion of Vernadsky's scientific works attributed to various fields of knowledge. 


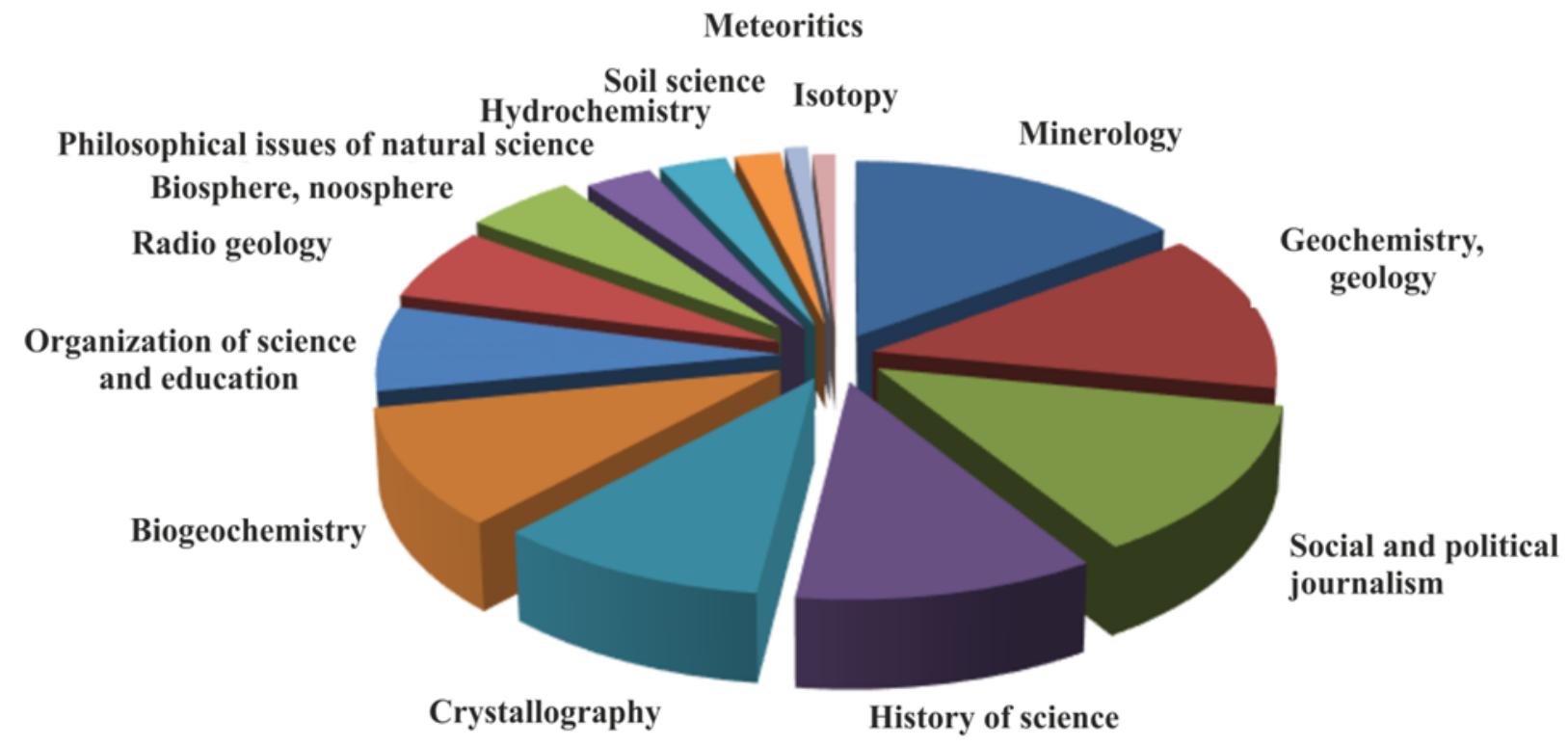

Figure 1. Scientific works of V.I. Vernadsky in various fields of knowledge.

Vernadsky has developed mineralogy and crystallography, laid the foundations of a new science, namely geochemistry, and organized a systematic study of radioactivity.

A very important thesis of Vernadsky's creative heritage is concluded in the following words: "We may face the future with confidence. It is in our hands." That is why the concept of "noosphere" is so important to us, since it brings us to "noospheric worldview", and also allowed the author of this article to introduce the concept of "noospheric balance" more than five years ago [15].

Balance is a system of indicators characterizing the ratio or equilibrium in any constantly changing phenomenon.

The awareness of the need for balance came also to the Club of Rome [9].

The Club of Rome sees synergy, i.e. the search for wisdom through reconciliation of opposites, and balance. Without claiming to be complete, the report of the Club identifies several areas in which balance needs to be struck between:

- man and nature;

- short-term and long-term prospect;

- $\quad$ speed and stability;

- individual and collective;

- women and men;

- equality and equity;

- state and religion.

These are particular balances. All of them have the right to exist, but they are combined into the balances of the economy, ecology, and social sphere. Each of them can be attributed to a particular area of sustainable development. 


\section{Sustainable Development Economy}

The economy determines our entire life. Balance in the economy, household balance, as well as the global balance of the economic world constitute the basis of the life of every person and every state. The imbalance causes conflicts and wars.

The great economist V.V. Leontiev was awarded the Nobel Prize for the developed method of interindustry balances. He "implemented" planning into capitalism, and the capitalism has won. The USA and Japan have used Leontiev's method, and the result is obvious. Deng Xiaoping took it a step further and implemented this "planned capitalism" into the socialist system of China.

Leontiev often wondered, what kind of society and what economy Russians would like to build on the ruins of communism in Russia. "Sometimes it seems that they want capitalism, which is no longer in the West. But international experts are also mistaken, when they think that the countries of the former Soviet Union are facing a fairly simple task, the solution of which is known from the textbooks of macroeconomics" [16].

For a year with a little before his death, V.V. Leontiev puts dots over the "i" in an interview with "Komsomolskaya Pravda": "The authorities could not create an elementary civilized living conditions for those with whom entrepreneurship begins ... But it was necessary to begin with this ... It was impossible to dispense remnants so thoughtlessly, let the backward, but still powerful Soviet economy". "Is government intervention in the economy necessary?" Yes, to the extent that it encourages civilized entrepreneurship. "Thus, in the speeches of V.V. Leontief in the 1990's outlined the contours of a new socio-economic policy for Russia.

Combining the concepts and thoughts of Vernadsky and the ideas of Leontiev, we can say that Leontiev has created a "noospheric economic balance". After the last visit to Russia, Leontiev said: "I will never go there anymore. They do not listen to anything." Russia has taken the path of capitalism in its worst manifestation.

According to the latest report, responsible executives of the Club of Rome and its leading experts have come to a firm conclusion about the inevitability of a radical change in the development paradigm of our civilization. Harsh criticism of capitalism, rejection of financial speculations, a call for an alternative economy, "new Enlightenment", spiritual and moral worldview, and a single planetary harmonious civilization is the today's agenda for future development proposed by the Club of Rome [9].

The Club of Rome believes that in the 80 -ies of the last century, capitalism has degenerated, while the main source of profit was financial speculation. This is one of the reasons for the global financial crisis of 2008-2009. But bankers not only retained their positions, but also came out as winners: "They made themselves "too big to lose" or to go to prison" [9].

At the beginning of the last century Vernadsky writes a small memorandum on seven pages, where he notes: "Value is created not only by capital and labor. Creativity is equally necessary to create the object of value. The creative component of surplus value belongs to inventors and scientists. They are more robbed than workers. It is their achievements, their discoveries and inventions are used by entrepreneurs. And they are not in a hurry to share the profits. It is a rare case when a scientist, the inventor is also an able entrepreneur". [17]

It should be mentioned that the doctrine of the noosphere is noted by our leaders. The president of the Russian Federation Vladimir Putin at the APEC summit in 2010 said: "At the 
beginning of the twentieth century our compatriot Vladimir Vernadsky created a doctrine of a unifying space, the noosphere. It combines the interests of countries and people, nature, society, scientific knowledge and public policy. It is on the foundation of this teaching that the sustainable development concept is actually being built today".

It should be noted that China has applied the ideas of Vernadsky in practice and has demonstrated to the world that economic growth and scientific-and-technological advance are closely linked, and exactly the scientific-and-technological advance is the main driving force of economic growth. For clarity, we can compare indicators of economic development [22] of the three leading powers of the world, which are given in Table 1.

Table 1

Russia, China and the United States in figures

\begin{tabular}{|l|c|c|c|c|c|c|}
\hline \multirow{2}{*}{ Index } & \multicolumn{2}{c|}{ Russia } & \multicolumn{2}{c|}{ China } & \multicolumn{2}{c|}{ USA } \\
\cline { 2 - 7 } & $\begin{array}{c}1990 \\
\text { RSFSR }\end{array}$ & 2015 & 1990 & 2015 & 1990 & 2015 \\
\hline Territory, mil. km ${ }^{2}$ & 17,1 & 17,1 & 9,6 & 9,6 & 9,8 & 9,8 \\
\hline $\begin{array}{l}\text { Population at the end of the year, } \\
\text { mil.people }\end{array}$ & 148,3 & 146,5 & 1143 & 1374,6 & 253 & 322,8 \\
\hline Density of population, people/km 2 & 9 & 8,8 & 120,9 & 146 & 27,3 & 35,1 \\
\hline GDP, billion dollars, current prices & 1102 & 1326 & 390 & 11182 & 5980 & 18037 \\
\hline $\begin{array}{l}\text { GDP, taking into account purchasing } \\
\text { power parity, \$ bn }\end{array}$ & 1594 & 3725 & 1091 & 19696 & 5980 & 18037 \\
\hline $\begin{array}{l}\text { GDP, taking into account purchasing } \\
\text { power parity, world share, interest }\end{array}$ & 4,9 & 3,3 & 4,1 & 17,3 & 22,3 & 15,8 \\
\hline Oil production, million tons & 516 & 541 & 138 & 215 & 417 & 567 \\
\hline Coal production, million tons & 395 & 373,3 & 10547 & 3747 & 934 & 812,8 \\
\hline $\begin{array}{l}\text { Natural gas production, billion cubic } \\
\text { meters }\end{array}$ & 590 & 573,3 & 15,8 & 138 & 504,3 & 767,3 \\
\hline Electricity production, billion kWh & 1082 & 1063 & 621 & 5811 & 3185 & 4303 \\
\hline
\end{tabular}

For 25 years, the GDP of China has grown by $\mathbf{2 8 . 7}$ times, whereas in Russia GDP increased just by 1.2 times, and in the USA - by 3.02 times. The growth rate of China's economy is impressive and cannot be explained just by the high and ever-increasing population. China's GDP per capita has grown by 23.4 times.

Comparison of GDP growth with the growth of spending on science leads to the conclusion about the significant role of scientific-and-technological advance in the success of China (fig.2). 

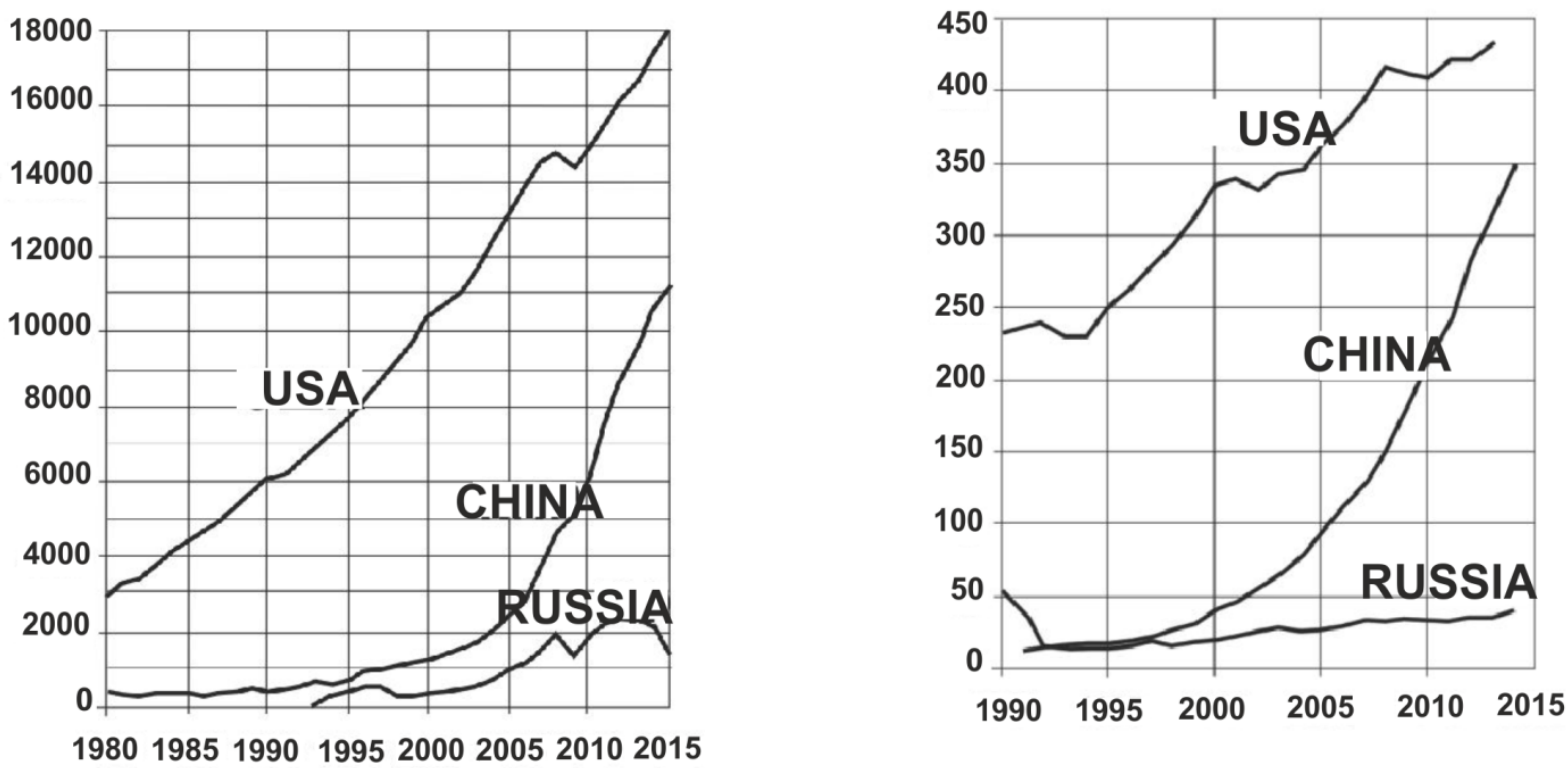

Fig.2. Comparison of GDR growth (a) and expenditure on science (b), \$ billion

We have already mentioned the statement of V.I. Vernadsky about the role of scientific and technical progress in economic development. Fig.3 compares the combination of factors of production with the liberal theory of free market development and how it should be, that is, as V.I. Vernadsky taught and as they did in China.

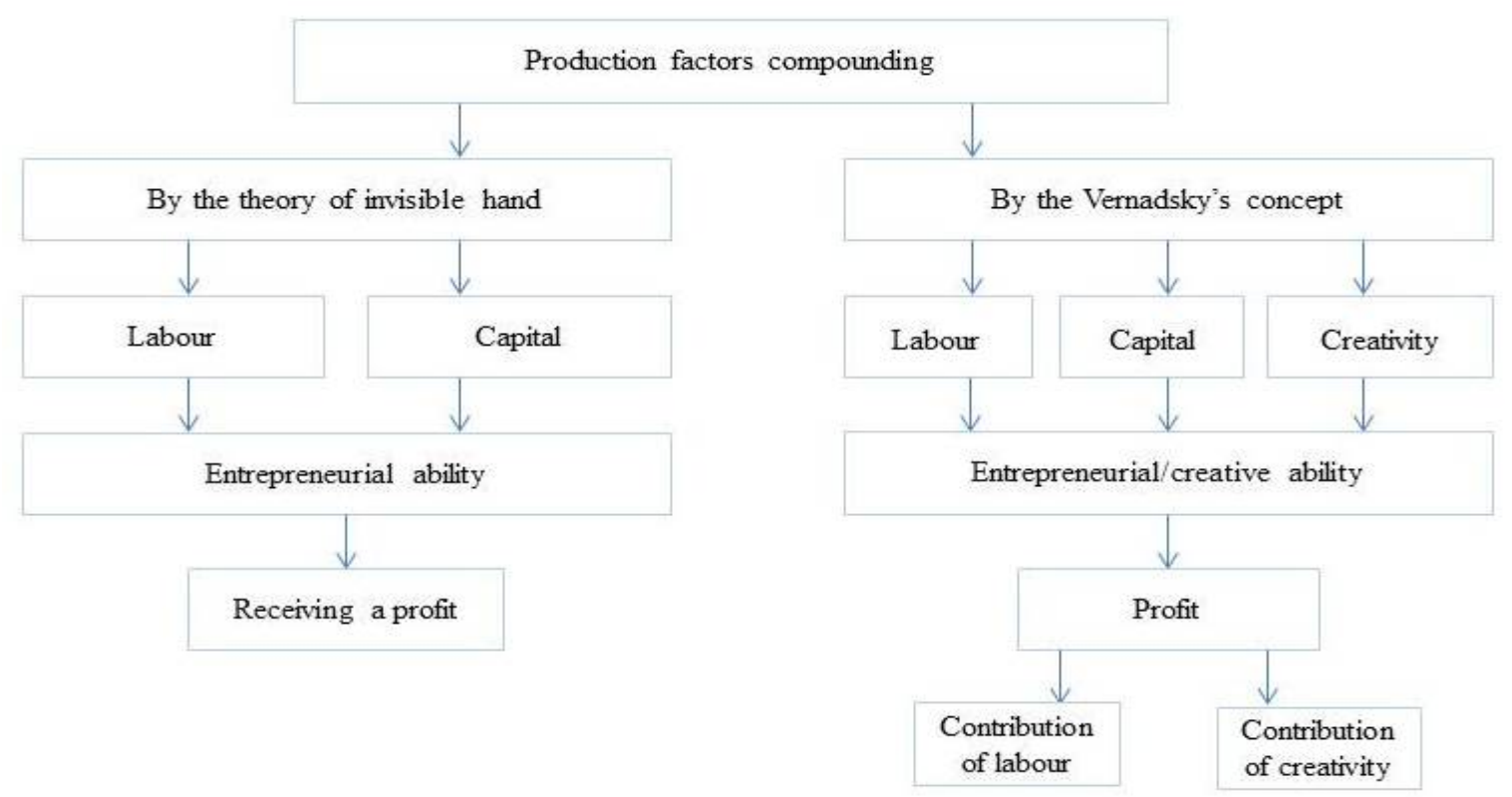

Fig.3. Economic components of sustainable development

Since the mid-1990s, the proportion of R\&D spending in China's GDP has almost quadrupled. Having overcome the 2\% line, the PRC, however, lags behind this indicator from a group of world leaders (Republic of Korea, Germany, Austria, Scandinavian countries, Japan, Taiwan, Israel, USA), where it reaches 3-4\%.

If measured in $\mathrm{CO}_{2}$ emissions (the surplus of which is considered to be the main cause of global climate change), one percent of the richest Americans generate 318 tons of $\mathrm{CO}_{2}$ emissions per year per person, while the average inhabitant of the land is six tons (a 53-fold difference). 
The basis for solving problems is scientific thought. V.I. Vernadsky wrote about this. The Roman club is cautious about the promises of techno utopians who believe that everything is decided by the NTP. There is a real danger of uncontrolled development and unethical use of technology and it is not yet clear how to avoid it. In addition, the promises of techno utopians demotivate people: if technology solves all problems, there is no need to search for complicated, complex solutions that require a lifestyle change" [9].

Not techno-utopianism, but noospheric balances, should solve the problem. And the Club of Rome comes to this conclusion through the search for wisdom: NOOS is the mind, the noospheric approach is wisdom.

\section{Sustainable development ecology}

Global environmental problems are well known and they are associated with global processes taking place both in space and the ground spheres. They can be divided into three groups:

- global climate change;

- global depletion of all types of natural resources;

- global pollution of the planet.

All of them are related to the imbalances, which primarily include the imbalance of energy, water, and resources.

There is just one way out of this situation, namely noospheric balances [15], i.e. balances based on reasonable consumption and accelerated reproduction in the global natural balance of the Universe, i.e. the balance of the Earth with the energy flux from space.

The solution to global environmental problems is laid in the global natural balance, which combines the processes of homeostasis in Nature and the power of the World Mind.

It is from Vernadsky's teachings that we know that scientific thought is the basis for solving global problems.

For example, a few centuries ago, horse dung was one of the global problems in London. "If we continue developing horse-drawn transport, London will be covered with a six-meter layer of horse dung," they said at that time. But this never happened, since invented cars replaced horses.

Any of today's global environmental problems has its solution. And it is based with an eye to a new scientific idea, i.e. on a creative approach to the problem. Let's consider three main problems: water, energy, resources.

The problem of water is not that it is not enough, the problem is that "it is not where it should be" and "not as it should be", that is salty. The solution is in the field of STP. Experiments on desalination have already been carried out by filtration through graphene, i.e. scientific progress in combination with nature-friendly technologies will solve environmental problems.

The problem of energy. Fossil fuels are exhaustible. An inexhaustible source is the substance $\mathrm{E}=\mathrm{mc}^{2}$. There is half the capacity of the Sayano-Shushenskaya HPP in $1 \mathrm{~kg}$ of it. In 1940 V.I. Vernadsky organized the Commission in the Academy of Sciences and created a government program to study uranium. It was the beginning of the USSR atomic program. Now Russia has the most effective two-component nuclear power system, based on nuclear reactors of the generation +3 and fast neutron reactors. This is a real way to a closed fuel cycle. 
The problem of the exhaustibility of resources is also solvable and also on the path of a closed cycle - a closed cycle of turnover of substances and materials.

In 1748, Lomonosov wrote to Euler: "... all the changes that happen in nature are such that states that as much as one body is taken away, so much will be added to another, so if some matter is lost, it will multiply in another place.

They are Russian scientists, such as M.V. Lomonosov and V.I. Vernadsky who with their scientific thought paved the way for the inexhaustibility of the possibilities of our civilization existence.

Global environmental problems associated with the pollution of the planet and anthropogenic impact on its existence, will also find their solution as a result of scientific advances. Pollution is the same "horse manure" of London six centuries later.

The problem of global warming deserves special attention, first of all, because there is no such problem. In fact the problem is associated with global climate processes. They are cyclical, and it is obvious that they do exist. In historical retrospect, there were ice ages, and there were periods of warming and, apparently, this will again occur in future. At present, the problem of anthropogenic climate warming is widely discussed. Moreover, a significant part of the society has recognized it and actively joined the "struggle" against this phenomenon.

In our opinion, nature compensates the anthropogenic impact on the climate by natural homeostasis.

Homeostasis in global climate change is based on the processes taking place in the biosphere. Certainly, extracting carbon from the subsoil, where nature has "hidden" it for many decades, mankind has significantly reduced the period of its turnover, but these processes are compensated by the fact that the main greenhouse gas $\mathrm{H}_{2} \mathrm{O}$ is involved in global compensation through its natural rate of turnover, and the increase in anthropogenic $\mathrm{CO}_{2}$ leads to faster growth of biomass that can be evaluated as a positive phenomenon. Vernadsky in his work [18] noted the role of the biosphere in climatic phenomena. He noted that chemical meteorology and climatology were not yet sufficiently developed for weather forecasting. More than half a century has passed, but his statements are still relevant. The impact of other greenhouse gases is even less significant. Short-lived methane has almost no impact on the climate ${ }^{2}$, while anthropogenic methane, as studies on isotope $\left({ }^{12} \mathrm{C},{ }^{13} \mathrm{C}\right)$ composition of various sources [19] have shown, does not affect the climate at all. Why the pressure from those, who recognize the anthropogenic origin of climate warming, is so strong?

The US President Donald Trump spoke out as follows: "Anthropogenic warming is a hoax invented by the elite in order to make money on it." This quote immediately gives an answer to many questions that have arisen among specialists in the last 15-20 years. And even if the American president calls a whistle around the "warming" of hoaxes, it seems that the authors of this hoax are at the higher positions of the world elite than Donald Trump himself. So the scientific problem is solved not according to the scientific scenario.

\footnotetext{
2 According to the University of London, the National Oceanography Center and the Center for Atmospheric Science (UK), National Oceanic and Atmospheric Administration, the Institute of Arctic and Alpine Research (USA), Victoria University of Wellington (New Zealand), Laboratory for Sciences of Climate and Environment (France), and South African Weather Service.
} 
Here are statements of some authoritative scientists. Academician O.N. Florensky was heading the Council of the Russian Academy of Sciences on energy development issues in Russia. He wrote: "For many years mass media's propaganda of the fact that man influences the climate is a deliberate deception. I explain why. During 15 years we are publishing works that show that in the radiant heat exchange of "Space - Earth" system, 60\% of all types of radiation from ultraviolet to infrared are determined by water vapor, whereas the contribution of carbon dioxide is only $4 \%$ ! At that, water vapor is directly dependent on the temperature of the ocean. Therefore, the climate is connected with water vapor, rather than with carbon dioxide."

The British Royal Geographical Society hosted a lecture "Global environmental issues from Peter the Great to the present day" delivered by the famous Russian geographer, Corresponding Member of the Russian Academy of Sciences, Professor A.P. Kapitsa, in which Professor mentioned that at the times of Peter the Great, it was much colder in Europe than today, and that many of today's environmental problems date back to that time. In his lecture, he argued that the fashionable theories of global warming and ozone holes are nothing more than pseudoscientific myths [20].

This statement runs counter to the 1995 Madrid Intergovernmental Conference, at which the UN proclaimed global warming a scientific fact. A number of documents submitted to the UN by opponents of the global warming hypothesis have disappeared without a trace. These documents did not appear at the conference. The approach, as well as the statement, was obviously one-sided.

There are many articles in the modern scientific literature that refute the fact of global warming [24-27].

Dean Burnett [23] in his article "Climate change is an obvious myth", published in the Guardian, writes: "Many people simply refuse to accept the facts that surround them." Sean Martin and Jennifer Marohasy [18] in their publications cite the evidence base in favor of the fact that global warming is a natural process [25].

Doctor Fred Singer [26], the first Director of the American Meteorological-Satellite Service and Dr. Frederick Seitz, physicist, President of Rockefeller University and the National Academy of Sciences, argue that developed computer models are based on questionable data and use assumptions that ensure the answers to the questions about the nature and global warming trends that scientists expect to obtain.

The letter against the warming problem politicization is signed by 31,000 scientists including 9,000 Ph.D. holders and professors. Scientists are protesting against the primitive concepts of anthropogenic warming, carbon taxes, and restrictions on economic growth. They believe that global climate agreements are destructive to the vegetation and animals' life on the planet [27]. The petition of scientists was also accompanied by a letter from Seitz, President of the National Academy of Sciences of the USA. The letter warns of the unscrupulousness of science directed against carbon dioxide, which is not only nonhazardous gas but is in fact a molecule of life. Vernadsky spoke about the role of the biosphere in the climate long before all discussions have started [18].

To a large extent, this is due to global processes that contribute to sustainable development. 


\section{Sustainable Development States}

Having considered economic and environmental problems in the light of Vernadsky's creative heritage, we inevitably come to the consideration of the social component of sustainable development.

Correlations of ecology and economy create acceptable or unacceptable conditions; correlations of ecology and social sphere create admissible or intolerable conditions; while correlations of the economy and the social sphere create fair or unfair conditions.

Unfair conditions upset the social balance in the society and are the basis of conflicts, revolutions, and wars. Acceptable, admissible, and fair conditions are achieved by the observance of balances.

Economic imbalances are created by speculative capital. A new formula of capitalism "moneyair-money" instead of classical definition "money-commodity-money" has become a dream of nonmanufacturing businessmen. The Club of Rome in its latest report [9] has subjected modern capitalism to harsh criticism, though speculative capital does not give up. Cryptocurrency is its recent "achievement".

Unfortunately, in fact, making a profit by fraudulent methods has swept the whole world and becomes dangerous. To a large extent, this applies to the economic aspect of the Kyoto Protocol and the Paris Agreement. Cryptocurrency and climate money are of the same nature as financial pyramids. In 2019, this type of fraud will be 100 years old. The first pyramid was created in 1919 by the Italian Charles Ponzi.

While considering the global climate problem in comparison with fraud in the financial sector, we can state that the world will be destroyed by global fraud of speculative nature rather than by global warming.

Progressive forces of mankind understand this and set "Goals targeted to sustainable development" [28]. All the 17 goals are associated with Vernadsky's creative heritage. Each of the goals can be quoted from the works of the scientist. Thus, with respect to Goal 1 "Elimination of poverty" and Goal 2 "Elimination of hunger", Vernadsky wrote in $[29,30]$ about ways to achieve the wealth of the country, which would eliminate hunger and poverty: "The harder and worse the economic situation of the country, the more economically formidable it is, the more resolutely it is necessary to embark on a path of large material resources for the creation of national wealth, the inevitable prerequisite of which is now scientific knowledge" [29].

Hunger is not a natural phenomenon, but a social problem that requires reform. "While the crop failure is a natural disaster that is not yet completely amenable to the power of science and technology, then hunger, as its consequence, is a social phenomenon, which can and should be foreseen in advance and prevented. And if, after all, crop failure turns into hunger, this is not just a great disaster for the country, but also a terrible symptom, indicating a fundamental disorder of the entire state mechanism, the need for the fastest and most decisive measures of state renewal" [30].

Vernadsky saw the way out of many of our troubles in education and in strengthening the role of scientific knowledge. He believed that it was necessary to organize education throughout a person's life: "Higher education of our time is now in a mobile state, in an era of rapid growth" [30]. 
The solution to environmental problems is one of Vernadsky's core ideas. Thus, on the problem of water, he wrote a book "History of natural waters" [31], which revealed the issues of water management and conservation. Vernadsky writes: "Water stands alone in the history of our planet. There is no natural body that could be compared with water in its influence on the course of the main, most grandiose geologic processes". There is no earthly matter - a mineral, a rock, a living body, which does not include it ... Water is the most important substance and controls dynamics of all life " (Goals 6 and 14).

In terms of the role of science and scientific thought, Vernadsky's heritage is relevant even today, since scientist tasks directing efforts towards mastering the sources of energy and water, wind, and solar radiation. "To reduce precisely, scientifically, all this diversity to one unit-measure, to express the energy and natural productive power and national wealth - is a general scientific problem of great practical importance rather than the theoretical knowledge. Applied science should present a natural-scientific picture of the part of nature, which can be turned into a human national wealth and which human really turns into wealth during his centuries-old life." "Do we have to wait for hundred thousand years to create oil, or a human can intercept this process and get immediately the bodies he needs, that are currently obtained from oil and its original bodies such as sapropel, and in particular, sapropelites?" [32].

V.I. Vernadsky created the "Commision for the Study of Natural Productive Forces" [33], which modern economists recently destroyed, because it does not fit into the system of fraud with speculative capital. Vernadsky wrote: "The state system will be" durable and effective only if a free, large organization of profound scientific work is provided for and foreseen in it. In the near already in the second half of the 20th century, judging by the pace and power of scientific achievements of recent decades - it will become inevitable and self-evident. "Institutes should be organized on problems, not sciences. Ideally, the deeper and deeper the problem, the greater the power of achievement"[33].

Above we quoted the role of creativity, which Vernadsky considered as the main component of development. He saw this as a solution to the Goal 9 of "Industrialization" [34]. "Who produces creative work in the industry? Whose labor should be paid mainly? It seems to me, that usually it is neither a worker nor a capitalist. This is the organizer and inventor". [33].

He also expressed valuable and relevant ideas with respect to Goal 10 [35] and Goal 11 [36].

With regard to the climate, which is now "on trend" (Goal 13), Vernadsky wrote [18]: "Biogenic oxygen, transforming into ozone, protects life against the destructive action of ultraviolet rays of the Sun, completely absorbing those rays which are fatal to the life on Earth. Life, a living substance, as it were creates itself an area of life. Yet we are not sufficiently studying this one of the basic chemical processes going in our gas shells. We can say that chemical meteorology and climatology are still in the first stage of their development and it seems to me, this is one of the reasons for their insufficient use for weather forecasting" [29].

With respect to the biosphere (Goal 15), Vernadsky's works received worldwide recognition $[38,39]$. The main idea of Vernadsky's concept can be formulated as follows: the biosphere is the basic geological shell of the planet, controlled by biota.

With regard to the Goal 16 of "Peace, justice, and effective institutions" and Goal 17 of "Partnership for sustainable development", his ideas of the noosphere and scientific thought as a planetary phenomenon [40] are relevant even today and will be relevant for future generations. 


\section{CONCLUSION}

The radical reconstruction of our country must be based on scientific thought - daring, deep and free, looking for new ways. This is one of the most basic conditions for success.

The creative heritage of Vernadsky clearly shows that the basis for meeting the global challenges of modern civilization is scientific thought. The solution of the global problems is associated with noospheric balances which combine global natural balances and the world mind as the basis of the noosphere.

Academic papers of the scientist are closely associated with the Goals of sustainable development proclaimed by the UN in the Resolution of 25.09.2015 "Transforming our world: the 2030 Agenda for Sustainable Development". They serve the scientific and methodological grounds for the implementation of the 17 sustainable development goals to transform our world. The ideas expressed by Vernadsky are still relevant today.

Scientific heritage of V.I. Vernadsky indicates a reasonable path of sustainable development, namely noosphere genesis. Global mind and collective intelligence as the basis of noosphere worldview allow solving all the problems of sustainable development.

\section{References}

Vernadsky V.I., 1945. The biosphere and the noosphere. Am. Scientist, 33(1), pp. 1-12.

Galimov E.M. V.I. Vernadsky and the present. Report at the solemn meeting dedicated to the 150th anniversary of the birth of VI Vernadsky in the Presidium of the Russian Academy of Sciences. Noosphere, 2013.

Aksenov, G.P., 2010. Vernadskij [Vernadsky] [Text]. 2 ${ }^{\text {nd }}$ ed., Life of Wonderful People, Biography Ser., 1208, Moscow, Molodaya Gvardiya, 565 p.

Grachev, V.A., 2013. Noosfernoe mirovozzrenie i ustojchivoe razvitie [Noospheric world view and sustainable development] [Text]. Contribution of V.I. Vernadsky to the development of world civilization, Moscow.

Noosfera №2 [Noosphere No. 2] [Text], 2018. Journal of the Vernadsky Ecological Foundation, Moscow, 75 p.

Vernadsky V.I., 1944. Neskol'ko slov o noosphere [A few words about the noosphere] [Text]. Successes of Modern Biology, 18, pp. 113-120.

Vernadsky, V.I., 1922. My podhodim k velikomu povorotu v zhizni chelovechestva [We are approaching a major shift in the life of mankind] [Text]. Introduction to the book "Essays and Speeches". Ed. 1, 2. Petrograd.

Vernadsky V.I. We come to a great turn in the life of mankind, 1922 / On science. Volume 1. Scientific knowledge. Scientific creativity. Scientific thought. Dubna: Phoenix. 1997. - 576 p.

Weizsaecker, E. and Wijkman, A., 2018. Come on! Capitalism, short-termism, population and the destruction of the planet. Springer, $220 \mathrm{p}$.

Vinogradov, A.P., 1954. V.I. Vernadskij [V.I. Vernadsky] [Text]. Essays on Geochemistry, 1, Moscow, Publishing House of the USSR Academy of Sciences, 696 p.

Vernadsky VI Selected works in 5 volumes. Biosphere and noosphere. Moscow: Iris Press, 2008. 576 pp. (Serial Library of History and Culture).

Naumov, G.B. and Sorokina, M.Yu., 2001. Vernadskij V.I. Izbrannye sochineniya v 5 tomah. Biosfera. [Vernadsky, V.I. Selected works in 5 volumes: Biosphere] [Text]. Thoughts and sketches, Collection of academic papers. Moscow, Noosphere Publishing House, 244 p.

Vernadsky, V.I., ZHivoe veshchestvo i biosfera [Living matter and the biosphere] [Text]. Edited by Yanshin, A.L.. Moscow, Science, 1994, 669 p.

Ilyin IV, Ursul AD, Ursul TA Noospherogenesis as a global process (concept of nooglobalistics) // Bulletin of Moscow University. Ser. XVII: Globalistics and geopolitics, 2014. № 1/2. Pp. 37-54.

Osipov, V.I., Aksyutin, O.E., Ishkov, A.G., and Grachev, V.A., 2018. Vzaimodejstvie cheloveka s estestvennoj sredoj: Osnovnoj faktor sushchestvovaniya civilizacii [Interaction between man and the natural environment: A major factor of the existence of civilization] [Text]. Bulletin of the Russian Academy of Sciences, 88(1), pp. 7-14. 
Leontiev V.V. Economics: method and costs - output. M., 1966. p. 11 - 15.

Volkov, V.P., 2001. Dnevniki V.I. Vernadskogo, 1926-1934 [V.I. Vernadsky's diaries, 1926-1934] [Text]. Moscow, Science, (Collection of Academician V.I. Vernadsky's writtings), 456 p.

Vernadsky, V.I., 1965. Himicheskoe stroenie biosfery Zemli i ee okruzheniya [Chemical structure of the Earth's biosphere and its environment] [Text]. Moscow, Science, 374 p. (duplication).

Nisbet, E.G., Dlugokencky, E.J., Manning, M.R., etc., 2016. Rising atmospheric methane: 2007-2014 growth and isotopic shift. Global Biogeochemical Cycles, pp. 1356-1370.

Kapitsa A.P. Obman planetarnogo masshtaba [Deception of a planetary scale] [Text]. Retrieved 19.03.2018 from http://www.mirprognozov.ru/prognosis/climate/globalnoe-poteplenie-loj-veka.

Roginko S.A. A great climatic conspiracy. Top Secret, No. 2/391, 2017.

Gorodnitsky A. End of the myth of global warming. Newspaper "New News »[Electronic resource]: URL:https://ss69100.livejournal.com/3206935.html (circulation date is March 19, 2013)

Burnett, D., 2014. Climate change is an obvious myth - how much more evidence do you need? The Guardian, 25.11.2014. Retrieved 21.03.2018 from www.theguardian.com/science/brain-flapping/2014/nov/25/climatechange-is-an-obvious-myth-how-much-more-evidence-do-you-need (circulation date is March 21, 2018)

Marohasy, J., 2017. Most of the recent warming could be natural. Retrieved 21.03.2018 from http://jennifermarohasy.com/2017/08/recent-warming-natural

Sean Martin. Climate Change - the REAL inconvenient truth: Scientist claims global warming is NATURAL. Express, Aug 25, 2017. https://www.express.co.uk/news/science/845901/climate-change-natural-global-warmingevidence-jennifer-marohasy (circulation date is March 21, 2018).

Karin McQuillan. Scientists in Revolt against Global Warming, 2011. URL:

https://www.americanthinker.com/articles/2011/11/scientists in revolt against gl obal warming.html (circulation date is March 21, 2018 ).

Adrian Sol. 31000 Scientists Speak Out Against Global Warming Hoax. Daily Stormer, 2017. URL:

https://dailystormer.name/31000-scientists-speak-out-against-global-warming-hoax (circulation date is March 21,2018 ).

Resolution of the UN General Assembly No. 17 / RES / 70/1. Transformation of Our World: An Agenda for Sustainable Development for the period until 2030, 2015. 44s.

Vernadsky, V.I., 1928. O zadachah i organizacii prikladnoŭ nauchnoı̆ raboty Akademii nauk SSSR [On tasks and organization of applied scientific work of the USSR Academy of Sciences] [Text]. Leningrad, Publishing House of the USSR Academy of Sciences, 42(1). (Reports of the Commission for the Study of Natural Productive Forces, 20).

Vernadsky, V.I., 1905. Novoe bedstvie [New disaster] [Text]. Russian Bulletin, August 4, 1905.

Vernadsky, V.I., 1905. Blizhajshie zadachi akademicheskoĕ zhizni [The immediate tasks of academic life] [Text]. Statutory Power, 24.

Vernadsky, V.I., 1936. Istoriya mineralov zemnoŭ kory [History of minerals of the Earth's crust] [Text]. History of natural waters. 2(3). Leningrad, Department of Scientific and Technical Information - Khimteoret, 2, IV, pp. 403562 .

Vernadsky, V.I. 1928. O zadachah i organizacii prikladnoı̆ nauchnoı̆ raboty Akademii nauk SSSR [On tasks and organization of applied scientific work of the USSR Academy of Sciences] [Text]. Leningrad, Publishing House of the USSR Academy of Sciences, 42(1), (Reports of Commission for the Study of Natural Productive Forces, 20).

Vernadsky, V.I., 1921. Zapiska o neobhodimosti sozdaniya Komissii po izucheniyu istorii nauki, filosofii i tekhniki [Note on the need to create a Commission on the history of science, philosophy and technology] [Text]. May 14, 1921. Bulletin of the Russian Academy of Sciences, Ser. 6, (15, 1/18). pp. 1-12.

Vernadsky, V.I. Dnevniki, oktyabr' 1917 - yanvar' 1920 [Diaries, October 1917 - January 1920] [Text]. Ed. by K.M., Sytnik. Kyiv, Naukova Dumka, 1994, 270 p.

Vernadsky, V.I, 1913. Zadachi vysshego obrazovaniya nashego vremeni [Problems of higher education of our time] [Text]. Bulletin of Education, 6, pp. 1-17.

Vernadsky, V.I., 1916. Ob ispol'zovanii himicheskih ehlementov v Rossii [On the use of chemical elements in Russia] [Text]. Russian Thought. 1, pp. 73-88. 
Vernadsky, V.I., 1926. Biosfera [Biosphere] [Text]. Nauchkhimtekhizdat, 146 p.; Same: La biosphére. Paris, F. Alcan, 1929. XII, 232 p. (Nouvelle collection scienti que); The biosphere. L.: Synergetic-Press, 1986.82 p.

Vernadsky VI The chemical structure of the Earth's biosphere and its environment. Moscow: Nauka, 1965.374 p.

Vernadsky, V.I.. Nauchnaya mysl' kak planetnoe yavlenie [Scientific thought as a planetary phenomenon] [Text]. Reflections of a Naturalist. 1-2, Moscow, Science, 1975-1977, 191 p. 